\title{
Promoción de destinos turísticos a través de las series audiovisuales. El caso de Juego de Tronos
}

\author{
ESTHER GONZÁLEZ-VÁZQUEZ ${ }^{a}$, \\ NOELIA ARAÚJO-VILA ${ }^{b}$
}

pp. $63-82$

\begin{abstract}
RESUMEN Este artículo muestra la importancia que puede tener el sector audiovisual como herramienta promocional del sector turístico. Por tanto, se analiza un caso concreto de actualidad, la serie Juego de Tronos, con el objetivo de conocer de qué manera influye sobre los destinos que sirvieron de escenario para su rodaje. La metodología empleada es la técnica cualitativa de análisis de contenido, por medio de la cual se analizan 45 sitios web oficiales de destinos turísticos. Se concluye que se crean en la actualidad productos turísticos relacionados con la serie, y en algunos destinos se utiliza como instrumento de promoción turística. Sin embargo, no se aprovecha la totalidad de los beneficios que la serie podría aportar al destino turístico.
\end{abstract}

PALABRAS CLAVE promoción turística, producto turístico, turismo, series.

\section{HISTORIA DEL ARTÍCULO}

¿CÓMO CITAR?:

González-Vázquez, E. \& Araújo-Vila, N. (2018). Promoción de destinos turísticos a través de las series audiovisuales. El caso de Juego de Tronos. Perspectiva Empresarial, 5(2), 63-82. http://dx.doi. org/10.16967/rpe.v5n2a5

RECIBIDO: 16 de noviembre de 2017 APROBADO: 13 de mayo de 2018

CORRESPONDENCIA:

Noelia Araújo-Vila. Facultad de CC Empresariales y Turismo, 32004 , Ourense, España.

a Magíster en Dirección y Planificación del Turismo Interior y de Salud. Universidad de Vigo, España. Correo electrónico: esthergonzalezvazquez@gmail.com

b Doctora en Dirección y Planificación del Turismo. Profesora invitada en la Universidad de Vigo, España. Correo electrónico: naraujo@uvigo.es 


\section{¿CÓMO CITO EL ARTÍCULO? HOW TO CITE THIS PAPER?}

CHICAGO:

González-Vázquez, Esther y Araújo-Vila, Noelia. 2018. "Promoción de destinos turísticos a través de las series audiovisuales. El caso de Juego de Tronos". Perspectiva Empresarial 5(2): 63-82. http://dx.doi.org/10.16967/ rpe.v5n2a5

MLA: González-Vázquez, Esther y Araújo-Vila, Noelia. "Promoción de destinos turísticos a través de las series audiovisuales. El caso de Juego de Tronos". Perspectiva Empresarial 5.2 (2018): 63-82. Digital. http:// dx.doi.org/10.16967/rpe. v4n2a1

\section{Promotion of Tourist Destinations through TV Series. The Case of Game of Thrones}

ABSTRACT This article shows the importance that the audiovisual sector may have as a promotional tool for the tourist sector. For this purpose, a specific case-Game of Thrones-is analyzed to know how it influences the destinations that served as locations for its shooting. The method used is the qualitative technique of content analysis, whereby 45 official websites of tourist destinations are analyzed. It is concluded that tourist products related to the series are being created and, in some destinations, it is used as an instrument to promote tourism. Nonetheless, not all the benefits that the series could bring to the tourist destination are used.

KEYWORDS tourist promotion, tourist product, tourist industry, TV series.

\section{Promoção de destinos turísticos através das séries audiovisuais. 0 caso de Game of Thrones}

RESUMO O presente artigo mostra a importância que pode ter o setor audiovisual como ferramenta promocional do setor turístico. Portanto, um caso concreto da atualidade é analisado, a série Game of Thrones, com o objetivo de conhecer de que maneira influencia os destinos que serviram de cenário para sua filmagem. A metodologia utilizada é a técnica qualitativa de análise de conteúdo, por meio da qual 45 páginas web oficiais de destinos turísticos são analisadas. Conclui-se que, na atualidade, são criados produtos turísticos relacionados à série e que, em alguns destinos, eles são utilizados como instrumento de promoção turística. Porém, a totalidade dos benefícios que a série poderia oferecer ao destino turístico não é aproveitada.

PALAVRAS CHAVE promoção turística, produto turístico, turismo, séries.. 


\section{Introducción}

Hoy en día, el turismo es un producto de consumo muy común en la vida de las personas, y un fenómeno en constante evolución, es decir, con el paso del tiempo surgen nuevos tipos de turismo.

Gracias a la industria del cine y, por extensión, a las series - las cuales no entienden de fronteras-, muchos destinos se posicionan como reclamo turístico. Por medio de la pantalla es posible transmitir ciertas imágenes a los espectadores, las cuales quedarán en sus mentes y las vincularán con el destino. Ejemplo de esto sería la promoción que hizo la película Vicky Cristina Barcelona (2008) de esta ciudad.

Tan solo hace dos décadas se dio a conocer el turismo cinematográfico y todavía son escasos los estudios relacionados con esta materia. En este trabajo se pretende avanzar en esta línea, pero en un producto diferente: las series. En concreto, analizar el caso de Juego de Tronos (2011-actualidad).

El turismo inducido por el cine, y por extensión las series, es el resultado del desplazamiento de turistas a un lugar tras observar una película que tuvo éxito (Buchmann, Moore y Fisher, 2010). Dependiendo del éxito del filme, el turismo cinematográfico perdurará más en el tiempo, o menos; es decir, a corto o a largo plazo, aporta en consecuencia puestos de trabajo y recursos económicos, así como contribuye a la desestacionalización turística a largo de la grabación y la trasmisión cinematográfica, e incluso luego según el éxito de la película.

El presente trabajo se centra en la vinculación serie audiovisual-destino turístico. Para esto, en primer lugar, se realiza una revisión de la literatura científica que existe sobre el uso de este tipo de turismo como promoción turística, la creación de productos turísticos a partir del turismo cinematográfico y el emplazamiento de destinos turísticos. A continuación, se explican los objetivos y la metodología de la parte práctica del trabajo, centrada en el caso de Juego de Tronos.

El objetivo principal de esta investigación es conocer de qué manera afecta Juego de Tronos, la serie de éxito del momento, el sector turístico, y verificar así si se usa como herramienta promocional de los destinos en que se ha grabado y si se crean productos turísticos derivados de ella. Para esto, el presente trabajo parte de una revisión de la literatura científica que existe sobre la promoción de destinos por medio de series. Luego, se explicará cuál es la metodología que se siguió para el estudio de caso de Juego de Tronos (análisis de contenido de los sitios web oficiales de los lugares en los que se ha rodado la serie), y así, a continuación, exponer los principales resultados y extraer unas conclusiones finales.

\section{Emplazamiento de destinos turísticos}

Una de las técnicas de publicidad que utiliza o crea marcas a través de los medios es la conocida como "emplazamiento del producto" (Redondo y Bernal, 2015). Es muy estimada en el caso del sector audiovisual, en el que el emplazamiento del producto forma parte del guion (Movilla Mengual, 2009): "El emplazamiento del producto es capaz de hacer que el público recuerde las marcas emplazadas, cambie de actitud hacia ellas e incluso acabe consumiéndolas" (Redondo y Bernal, 2015, p. 827).

Por norma general, los espectadores tratan de evitar los anuncios, bien sea con el cambio de canal (en el caso de la televisión), o a bien con el uso de una opción que permita "saltar" los los anuncios (en el caso de Youtube). Esto conlleva a que la publicidad mediante anuncios no pase por su mejor momento, de modo que como alternativa positiva se utiliza cada día más la técnica del emplazamiento de producto, con la cual, a través de un medio, se puede promocionar un producto o un destino. Un ejemplo de producto sería el caso del Renault Scenic, un coche que salía en la conocida serie Médico de familia (1995-1999), lo que provocó que se agotara en todos los concesionarios. Por su parte, un ejemplo de destino puede ser el caso del incremento del número de turistas en Nueva York gracias a algunas series o películas como Desayuno con diamantes (1961), o gracias a Mouline Rouge (2001) en el caso de París, o a El señor de los anillos (2001-2003) en el caso de Nueva Zelanda (Movilla Mengual, 2009).

El emplazamiento de destinos turísticos tiene como objetivo la atracción de turistas a una zona, así como promocionar y posicionar destinos a través de la pantalla. Puede darse por medio del cine, de videoclips, videojuegos, series, etc.; por tanto, en todo momento se habla del papel importante de los medios de comunicación y el turismo cinematográfico en el sector turístico, el cual, además, es mucho más económico que la publicidad (Bernad y Fernández, 2014). 
Esta investigación se centra en el emplazamiento de producto vinculado con los emplazamientos, lo cual se puede denominar "emplazamiento urbano". Desde el punto de vista turístico es interesante porque puede provocar un incremento importante en el número de desplazamientos turísticos a un lugar. Por este motivo, el emplazamiento del rodaje de una película o una serie no se elige por casualidad, pues existen factores económicos que interesan tanto a las autoridades competentes del destino como a los productores. Otros puntos relevantes del turismo de ciudad son (Méndiz Noguero, 2011):

- Género publicitario. Ámbito del emplazamiento de producto, comunicación híbrida entre entretenimiento audiovisual y promoción de lugares turísticos.

- Anunciantes específicos. Ciudades, regiones, monumentos, lugares turísticos y negocios de hospedaje y restauración.

- Vehículo de comunicación. Producciones audiovisuales, ya sean largometrajes cinematográficos, TV movies, cortometrajes, programas de variedades o de entretenimiento, videoclips, corporativos, spots publicitarios, etc.

- Ofrecimiento del lugar turístico. Ayuda en la financiación (exenciones fiscales, aportación de las arcas públicas, colaboración en la captación de fondos del empresariado local, etc.); o en el rodaje (concesión de permisos, facilitación de espacios públicos, comunicación con el vecindario, aportación de policía de orden y seguridad, alojamientos subvencionados como albergues, etc.).

- Beneficios que se esperan a cambio. Promoción del turismo local (incremento de visitantes), mejora de la imagen de la ciudad o destino (tanto a nivel nacional como internacional), posicionamiento como ciudad o destino turístico; y beneficios directos derivados del rodaje: impuestos para el ayuntamiento, pernoctaciones para los hoteles, comidas para los negocios de restauración, etc.

\section{Promoción turística a través de las series}

Para el desarrollo de esta investigación se considera necesario comenzar por definir dos conceptos vinculados en gran medida con el tema objeto de estudio: la imagen de un destino turístico y el turismo cinematográfico.

Imagen de destino turístico porque, según la imagen que un turista potencial tenga de un destino, se desplazará o no a ese lugar, por lo que se está ante un fenómeno con mucha importancia en el turismo. La imagen generada a través de las películas o las series puede ser positiva o negativa, tal y como se explicará más adelante.

También turismo cinematográfico porque tras realizar una revisión bibliográfica del turismo vinculado a series, son numerosos los estudios que, en primer lugar, hacen alusión al turismo cinematográfico, fenómeno más estudiado y con características y fines muy similares a la promoción turística a través de las series; incluso para algunos, las series son una extensión más del turismo cinematográfico.

En primer lugar, según Muñoz (2002, p. 8),

Se entiende por imagen de un destino turístico la percepción que el turista potencial tiene del destino en base a criterios de conocimiento y a criterios de afinidad o afectividad. Esto es, la imagen de un destino es la manera en que un turista manifiesta su posición hacia éste e incluso sus expectativas en torno al mismo.

Por su parte, Kim y Richardson (2003, p. 7) resumen la imagen de un destino como la "totalidad de impresiones, creencias, ideas, expectativas y sentimientos hacia un lugar acumulados a lo largo del tiempo".

En segundo lugar, de acuerdo con Buchmann et al. (2010, p. 233) el turismo cinematográfico es la "visita a un lugar o localización que ha sido empleado o está asociado con un rodaje”; y según Rodríguez y Fraiz (2010, p. 2), es la "actividad de ocio ligada a localizaciones geográficas relacionadas con el cine".

Se puede afirmar que el turismo cinematográfico es una modalidad turística bastante reciente, motivo por el cual aún no existen demasiados estudios o investigaciones relacionadas con esta temática. Algunos autores relacionan el turismo cinematográfico exclusivamente con las películas cinematográficas, y otros, como Roesch (2009), defienden que el turismo cinematográfico engloba tanto a las películas como a las series.

Los medios audiovisuales no son indiferentes para el turismo; estos tienen el poder de emitir las imágenes de un territorio dentro de una película o serie, y a su vez estimular a su espectador, quien 
acumula de manera progresiva determinadas emociones que posibilitan la generación de interés por desplazarse a ese lugar (Martínez y Hellín, 2014).

A través del cine y las series, los espectadores consiguen crear en sus mentes una imagen representativa de un lugar desconocido. El mundo audiovisual cobra mucha importancia en el ámbito turístico, es decir, una vez que los espectadores ven un lugar a través de la pantalla, este se convierte en turístico (Hernández, 2004). Es en ese momento cuando se despierta un interés por parte del espectador sobre el lugar que observa a través de su pantalla, el cual, acompañado de la creación de rutas, museos y demás elementos, genera el último impulso para que el espectador de esa serie o de esa película pase a ser turista y se desplace al destino en cuestión (Domínguez, 2014).

Existen diversos estudios turísticos que afirman el incremento del número de turistas a un lugar tras este aparecer como escenario en la gran pantalla del cine o en series de ficción. No solo es positivo el desplazamiento turístico, sino la generación de empleo y la contribución a la desestacionalización turística (Martínez y Hellín, 2014).

Se entiende que cualquier destino que busque obtener los beneficios de la tipología turística de la que se trata hasta ahora deberá poner interés en conseguir ser un escenario atractivo para las productoras, de tal manera que graben sus futuras películas o series en ese lugar (Roesch, 2009). De ahí la importancia de las film commissions (en España existen varias, entre ellas la Barcelona/Catalunya Film Commission, Andalucía Film Commission, o en Galicia, Galicia Film Commission).

Según Urry (1990), "el turista desea reconocer, revivir con la mirada, las imágenes que han sido anticipadas por la promoción turística, por encarnar éstas su anhelo de autenticidad"; por tanto, es muy importante que esa imagen se acerque lo máximo posible a la realidad para así cumplir las expectativas del consumidor (Mathieson y Wall, 1982). De acuerdo con Vives, "la imagen del destino turístico, ya sea real, ficticia o suplantada, influye mucho en la elección de nuestro destino de vacaciones o de visita" (Vives García, 2013, p. 79).

A continuación, se presenta una tabla de Vives (2013) (tabla 1) a partir de Hudson y Ritchie (2006), a modo de ejemplo, en la que se refleja la realidad de los efectos que se produjeron en los destinos a través de algunas películas.

En todos los casos, en mayor o menor medida, aumentó el turismo debido al rodaje de esas películas; esto es una muestra más de que se deben

TABLA 1. Efectos del cine en el turismo

\begin{tabular}{|c|c|c|}
\hline PELÍCULA & LOCALIZACIÓN & EFECTOS \\
\hline Braveheart & Wallace Monument, Escocia & Un $300 \%$ de incremento posterior al estreno. \\
\hline Mandolina del capitán Corelly & Cefalonia, Grecia & Un $50 \%$ de incremento. \\
\hline Field of dreams & lowa (Estados Unidos) & $\begin{array}{l}\text { Un total de } 35000 \text { visitas en 1991, e incrementos cada } \\
\text { año. }\end{array}$ \\
\hline Cuatro bodas y un funeral & $\begin{array}{l}\text { The Crown Hotel, Amersham, } \\
\text { England }\end{array}$ & Completo hasta tres años después del estreno. \\
\hline Harry Potter & United Kingdom & Un $50 \%$ de incremento en todas las localizaciones. \\
\hline Mission Impossible 2 & National Park, Sídney & Un $200 \%$ de incremento en el 2000. \\
\hline Troya & Çanakkale, Turquía & Un $73 \%$ de incremento. \\
\hline Nothing Hill & Kenwood House, Inglaterra & Un $10 \%$ en un mes. \\
\hline Pride and prejudice & Lyme Park, Inglaterra & Un $150 \%$ de incremento. \\
\hline Sense and sensibility & Saltram House, Inglaterra & Un $39 \%$ de incremento. \\
\hline The Beach & Tailandia & Un $22 \%$ de incremento de mercado joven en el 2000. \\
\hline The last Mohican & Chimmey Rock Park, Carolina & Un $25 \%$ de incremento al siguiente año. \\
\hline Encuentros en la tercera fase & $\begin{array}{l}\text { Devils Tower National } \\
\text { Monument }\end{array}$ & Un $74 \%$ de incremento. \\
\hline Memorias de África & $\begin{array}{l}\text { Shaba National Game Reserva, } \\
\text { Kenia }\end{array}$ & $\begin{array}{l}\text { De } 250 \text { ooo visitantes/año pasaron al año siguiente } \\
\text { a } 700 \text { 000, } \\
\text { crecimiento continuo: } 2008 \text {, dos millones de } \\
\text { visitantes. }\end{array}$ \\
\hline Cocodrilo Dundee & Australia & Un $20 \%$ de incremento de mercado americano. \\
\hline Crepúsculo & Forks, Washington, E. E. U. U. & Un $1000 \%$ gracias a las películas y a los libros. \\
\hline
\end{tabular}

Fuente: Vives García, M. (2013). Turismo inducido por el cine: aplicación del caso a la ciudad de Barcelona. Universitat de Girona, con base en Hudson y Brent (2006). 
aprovechar las oportunidades que ofrece el mundo audiovisual para atraer espectadores o turistas a un destino.

Dos ejemplos de destinos en los que aumentó la demanda turística por el éxito de las series fueron, fueron, Seattle (Estados Unidos) en el caso de Anatomía de Grey, a nivel internacional, y Lastres (Asturias, España) en Doctor Mateo, (Araújo y Fraiz, 2013). Otros éxitos similares y recientes son Gran Reserva en La Rioja o Gran Hotel en el Palacio de la Magdalena en Santander (Araújo y Fraiz, 2013).

Durante la emisión de las series Doctor Mateo y Gran Hotel las visitas aumentaron en un 60\% durante los dos primeros años, en el primer caso, y se triplicaron en el segundo (Marcos, 2014). Para que existan turistas inducidos por las series, primero es necesario que la serie consiga captar la atención de muchos espectadores; una vez se cumple este paso, lo más común es que mientras se emita la serie, los espectadores se conviertan en turistas del destino en cuestión, pero una vez se termina, ha de ser muy buena para que perdure en el tiempo; de lo contrario, el éxito del turismo inducido por las series se vería marcado por la propia duración de la serie (Navarro, 2015).

A continuación, se muestra una tabla elaborada por Araújo y Fraiz (2013) a partir de Hudson y Ritchie (2006, p. 389), y Busby y Klug (2001, p. 320 ), en la que se resumen los efectos de las series en los destinos.

\section{Creación de productos turísticos a través de las series}

Desde hace relativamente poco tiempo, tanto el cine como las series de ficción, en muchas ocasiones consiguen que los espectadores se conviertan en turistas. Es cierto que no se consigue con cualquier película o cualquier serie, sino que ha de tener un número importante de fanáticos que, guiados por sus emociones y sensaciones, es probable que tengan interés en visitar los escenarios del rodaje.

Al aprovechar ese interés de los espectadores o turistas, es significativo crear productos turísticos que generen valor al viaje. En la creación de productos turísticos se han de tener en cuenta dos factores sustanciales: la producción de una rentabilidad tanto económica y social como ambiental, y la satisfacción de la demanda.

Gracias a Internet, los turistas cada vez están más informados y se vuelven más exigentes, motivo por el cual la oferta turística se ve obligada a crear nuevos productos a fin de estar en capacidad de satisfacer sus necesidades. Los turismos de sol y playa, cultural, deportivo, de negocio y el rural ya no son suficientes para satisfacer esas necesidades, sino que se ven obligados a avanzar y especializarse más en profundidad; en el caso del turismo cultural, hoy se pueden distinguir subcategorías turísticas como el turismo enológico, el turismo gastronómico y el turismo cinematográfico, entre otros (Rodríguez, Fraiz y Alén, 2013).

Muchos países se inclinaron por el turismo cinematográfico con el propósito de dar a conocer, por medio del cine, su oferta (Martínez, 2008). A un destino no le es fácil diferenciarse en exclusiva de los otros ya que, de tener éxito, otro ofrecerá lo mismo a corto plazo. Por eso es necesario investigar y descubrir características o recursos propios, como, por ejemplo, la historia de un lugar, y así hacer que un destino tenga una oferta propia, única y, por tanto, difícil de imitar.

A través del sector audiovisual es posible llegar a muchos turistas potenciales, generarles una atracción o deseo por el destino que están viendo $\mathrm{y}$, consecuentemente, realizar el desplazamiento turístico. Previo al viaje, los turistas crean en sus mentes unas expectativas que han de cumplirse

TABLA 2. Efectos de las series en los destinos

\begin{tabular}{|c|c|c|}
\hline SERIE & LOCALIZACIÓN & IMPACTO EN EL NÚMERO DE VISITANTES O INGRESOS POR TURISMO \\
\hline \multirow[b]{2}{*}{ Pride and Prejudice } & Lyme Park & Crecimiento del $178 \%$ de visitantes tras su emisión en la BBC. \\
\hline & $\begin{array}{l}\text { Sudbury Hall, Derbyshire } \\
\text { (escenas de interior) }\end{array}$ & En 1996 los visitantes aumentaron un 59\% con respecto a 1995. \\
\hline Dallas & Southfork Ranch, Dallas & Un total de 500000 visitantes por año. \\
\hline Cheers (1982-1993) & Location in Boston & $\begin{array}{l}\text { Equivalente a siete millones de dólares de promoción a través de } \\
\text { promoción no remunerada. }\end{array}$ \\
\hline Miami Vice (1984-1989) & Miami & Incremento de visitantes alemanes en un $150 \%$ entre 1985 y 1988. \\
\hline
\end{tabular}

Fuente: Araújo, N. y Fraiz, J. A. (2013). Las series audiovisuales como herramienta promocional de un destino turístico: el caso de España. Investigaciones Europeas de Dirección y Economía de la Empresa, 19(1), 8-15 con base en Hudson, S. y Ritchie, J. B. (2006). Promoting destinations via film tourism: an empirical identification of supporting marketing initiatives. Journal of Travel Research, 44(4), 387-396, y Busby, G. y Klug, J. (2001). Movie-induced tourism: The challenge of measurement and other issues. Journal of Vacation Marketing, 7(4), 316-332. 
en el destino para ver satisfechas sus necesidades. Comienzan a formarse unas motivaciones basadas en revivir in situ los momentos vistos a través de la pantalla, es decir, el turismo experiencial (Martínez, 2008).

Al pensar en esos turistas para crear un valor añadido, aparecen los movie maps, los cuales son un ejemplo de los productos turísticos que surgen a través del turismo cinematográfico. Estos son mapas en los que se refleja un itinerario por los lugares que sirvieron de escenario en películas o series con información sobre estas (Hellín y Martínez, 2009). Normalmente, los crean las Film Comissions, las cuales aprovechan para incluir en los mapas cinematográficos la oferta de alojamiento y restauración de la zona (financiación pública) (Martínez y Hellín, 2014).

Otros productos serían las guías de viaje (financiación privada), las visitas guiadas, los platós y estudios de cine, los parques temáticos cinematográficos y los eventos (Vives, 2013). Según Martínez y Hellín (2014, p. 15), "es imprescindible acompañar el recorrido con animaciones de calle, actuaciones teatralizadas, acciones tematizadas e instrumentos tecnológicos que consigan la inmersión activa y lúdica del turista en el espacio ficcionado".

Podemos poner de ejemplo algunas series como la de Doctor Mateo, en la que se ha creado una ruta turística en Lastres y se realizan visitas guiadas (Hosteltur, 2011). El aumento del volumen de turistas conllevó la apertura de nuevos establecimientos, lo que supone generación de empleo y más oferta turística (El País, 2014). Otro ejemplo sería Sexo en Nueva York; con esta serie se ha creado una ruta turística en la que el desplazamiento se realiza en un autobús, con un guía y con una duración exacta de tres horas y media (Hosteltur, 2011).

Las series con más éxito suelen ser precisamente las que disponen de mapas cinematográficos o rutas, ya que son las que llegan a un mayor número de espectadores. Si se buscan las 10 series más descargadas del 2015 (Publico.es, 2015), se comprueba que ya tienen mapas cinematográficos cuatro de ellas (véase la tabla 3), lo que coincide con las cuatro más descargadas. Además, una de ellas se graba en interiores (en platós), por lo que no tiene sentido que tuviese mapa cinematográfico, ya que no hay escenas en exteriores y, por tanto, no se visionan destinos turísticos (The Big Bang Theory).
TABLA 3. Series más descargadas de Internet en el 2015

\begin{tabular}{lcc}
\hline SERIE & DESCARGAS & $\begin{array}{l}\text { MAPA } \\
\text { CINEMATOGRÁFICO }\end{array}$ \\
\hline Juego de Tronos & 14,4 millones & Sí \\
\hline The Walking Dead & 6,9 millones & Sí \\
\hline The Big Bang Theory & 4,4 millones & No (sitcom) \\
\hline Arrow & 4 millones & Sí \\
\hline The Flash & 3,5 millones & Sí \\
\hline Mr. Robot & 3,5 millones & No \\
\hline Vikings & 3,3 millones & No \\
\hline Supergirl & 3 millones & No \\
\hline The Blacklist & 2,9 millones & No \\
\hline Suits & 2,6 millones & No \\
\hline
\end{tabular}

Fuente: Elaboración propia por medio de BitTorrent. (2016, junio 15). BitTorrent [software]. Recuperado de http://www.bittorrent.com/lang/es

Según FormulaTv, las 10 series más puntuadas son las que se pueden ver en la tabla 4, y de ellas tienen mapa cinematográfico dos. Una vez más, se encuentra entre las series más puntuadas The Big Bang Theory que, por el motivo explicado, no se tendrá en cuenta. Lo mismo ocurre con Vis a Vis, La que se avecina y Modern Family. Respecto a Los pingüinos de Madagascar, es obvio que no tenga movie map, ya que se trata de dibujos animados.

TABLA 4. Series más puntuadas por los espectadores

\begin{tabular}{lcc}
\hline SERIE & PUNTUACIONES & $\begin{array}{l}\text { MAPA } \\
\text { CINEMATOGRÁFICO }\end{array}$ \\
\hline Vis a vis & 8,33 & $\begin{array}{c}\text { No (mayoría } \\
\text { grabada en plató) }\end{array}$ \\
\hline $\begin{array}{l}\text { La que se avecina } \\
\text { The Big Bang }\end{array}$ & 8,22 & $\begin{array}{c}\text { No (mayoría } \\
\text { grabada en plató) }\end{array}$ \\
\hline Sheory & 8,22 & $\begin{array}{c}\text { No (sitcom grabada } \\
\text { en plató) }\end{array}$ \\
\hline $\begin{array}{l}\text { Los pingüinos de } \\
\text { Madagascar }\end{array}$ & 8,15 & Sí \\
\hline $\begin{array}{l}\text { Rex, un policía } \\
\text { diferente }\end{array}$ & 8,12 & $\begin{array}{c}\text { No (son dibujos } \\
\text { animados) }\end{array}$ \\
\hline $\begin{array}{l}\text { Modern Family } \\
\text { Invación jurásica }\end{array}$ & 8,11 & No \\
\hline $\begin{array}{l}\text { Merlín } \\
\text { South Park }\end{array}$ & 8,08 & $\begin{array}{c}\text { No (sitcom mayoría } \\
\text { grabada en plató }\end{array}$ \\
\hline
\end{tabular}

Fuente: elaboración propia a partir de Formula TV.

\section{Caso de estudio: Juego de Tronos}

Juego de Tronos es una serie creada a partir de las novelas que hacen parte de la saga literaria Canción de hielo y fuego, escrita por George Raymond Richard Martin. La trama gira en torno 
a un mundo ficticio medieval formado por siete reinos: Reino del Norte, Reino de la Montaña y el Valle, Reino de las Islas y los Ríos, Reino de La Roca, Reino del Dominio, Reino de las Tormentas y el Principado de Dorne. Actualmente, presenta siete temporadas completas. Es la serie con más espectadores a nivel mundial, ya que se emite en 180 países. Se estrenó hace seis años en Estados Unidos y se ha rodado en diferentes localizaciones que se nombran más adelante.

Esta investigación se centra en la serie Juego de Tronos por ser una de las series más populares a nivel mundial. Se desarrolla en distintos lugares del mundo, como, por ejemplo, Irlanda, Malta, Croacia, Islandia, Marruecos y España. Si realizamos una búsqueda de la serie en diferentes ránquines, siempre la encontramos en las primeras posiciones. Por ejemplo, el Diario información (enero, 2016), enlista las series más esperadas por los espectadores para el 2016, y Juego de Tronos ocupa la segunda posición después de Expediente X. Según Sensacine, Juego de Tronos es la serie más valorada por los espectadores a nivel mundial, le siguen Breaking Bad y The Walking Dead. De acuerdo con BitTorrent, Juego de Tronos es la serie más descargada en el 2015.

Se trata de una serie que cautivó a millones de espectadores y dio lugar al movimiento de turistas cinematográficos. En el 2015, con respecto al 2014, se ha producido en Andalucía un aumento de turistas del $25 \%$, lo cual coincide con el rodaje de la quinta temporada de la serie (el $11 \%$ son extranjeros). Cabe indicar que 85000 personas presentaron su currículum para trabajar como extras en el rodaje, por lo que se está ante una generación de beneficios, tal y como se señala el portal windu.es.

A continuación, se muestra un desglose de los escenarios (tabla 5) más relevantes hasta la sexta temporada de Juego de Tronos. En el portal web Skyscanner se detallan los principales lugares de grabación en España, Marruecos, Islandia, Croacia, Irlanda del Norte, Malta y Escocia, y la correspondencia entre el lugar ficticio y el lugar real.

TABLA 5. Escenarios de Juego de Tronos en España

\begin{tabular}{|c|c|c|}
\hline ESPAÑA & & \\
\hline Lugar de Juego de Tronos & Escenario real & Temporada \\
\hline $\begin{array}{l}\text { Jardines del Agua del Reino de Dorne. } \\
\text { Residencia de los Martell (Lanza del Sol) }\end{array}$ & $\begin{array}{l}\text { Jardines, fuentes y habitaciones del Real } \\
\text { Alcázar de Sevilla }\end{array}$ & Quinta y sexta \\
\hline Arena de Meereen & Plaza de toros de Osuna (Sevilla) & Quinta y sexta \\
\hline Puente largo de Volantis (río Rhoyne) & Puente romano de Córdoba (río Guadalquivir) & Quinta y sexta \\
\hline $\begin{array}{l}\text { Antigua (Ciudadela), } \\
\text { Bravos o Desembarco del Rey }\end{array}$ & $\begin{array}{l}\text { Catedral, barrio judío y baños árabes de } \\
\text { Gerona }\end{array}$ & Sexta \\
\hline Mar Dothraki & Las Bardenas Reales de Navarra & Sexta \\
\hline Meereen & Peñíscola (Comunidad Valenciana) & Sexta \\
\hline Dorne & Alcazaba de Almería & Sexta \\
\hline Mar Dothraki o Vaes Dothrak & Pechina, Sierra de Alhamila y Almería & Sexta \\
\hline Colina Cuervo & $\begin{array}{l}\text { Castillo de Santa Florentina, Canet de Mar } \\
\text { (Barcelona) }\end{array}$ & Sexta \\
\hline Torre de la Alegría & Castillo de Zafra (Guadalajara) & Sexta \\
\hline \multicolumn{3}{|l|}{ MARRUECOS } \\
\hline Lugar de Juego de Tronos & Escenario real & Temporada \\
\hline Yunkai y Pentos & AïtBen-Haddou & Sexta \\
\hline Astapor & Essaouira & Segunda y tercera \\
\hline \multicolumn{3}{|l|}{ ISLANDIA } \\
\hline Lugar de Juego de Tronos & Escenario real & Temporada \\
\hline Baño termal "Nido de amor de Jon e Ygritte" & Grjótagj & Quinta \\
\hline Campamento de los Salvajes & Dimmuborgir & $\begin{array}{l}\text { Desde la tercera en } \\
\text { adelante }\end{array}$ \\
\hline Norte del Muro & Vatnajökull & $\begin{array}{l}\text { Desde la tercera en } \\
\text { adelante }\end{array}$ \\
\hline Las montañas de los Colmillos Helados & Höfoabreakka, Vík í Mýrdalur & Cuarta \\
\hline
\end{tabular}




\begin{tabular}{|c|c|c|}
\hline CROACIA & & \\
\hline Lugar de Juego de Tronos & Escenario real & Temporada \\
\hline \multirow{3}{*}{ Desembarco del Rey } & La ciudad vieja de Dubrovnik & \multirow{3}{*}{$\begin{array}{l}\text { Desde la primera en } \\
\text { adelante }\end{array}$} \\
\hline & Palacio de Diocleciano Split & \\
\hline & Murallas de Ston & \\
\hline Casa de los Eternos & Torre Minceta & Segunda \\
\hline La Fortaleza Roja & \multirow{2}{*}{ Fortaleza de Lovrijenac } & \multirow{2}{*}{$\begin{array}{l}\text { Desde la temporada dos } \\
\text { en adelante }\end{array}$} \\
\hline Batalla del Aguasnegras & & \\
\hline Quarth & Lokrum & Segunda \\
\hline Jardines de Desembarco del Rey & Arboreto de Trsteno & $\begin{array}{l}\text { Desde la segunda } \\
\text { temporada en adelante }\end{array}$ \\
\hline Braavos (Ciudad Libre) & Sibenik & Quinta \\
\hline Paisajes de Poniente & Parque Nacional de Krka & $\begin{array}{l}\text { Desde la tercera } \\
\text { temporada en adelante }\end{array}$ \\
\hline \multicolumn{3}{|l|}{ IRLANDA DEL NORTE } \\
\hline Lugar de Juego de Tronos & Escenario real & Temporada \\
\hline Bosques del Norte & Parque Nacional de Tollymore & Primera \\
\hline Invernalia & Castillo Ward & Primera \\
\hline Playa de Roca Dragón & Templo de Mussenden y Playa de Downhill & Segunda \\
\hline Carretera desde Desembarco del Rey & The Dark Hedges & Segunda \\
\hline Puerto Noble (puerto de Pyke, Islas del Hierro) & Puerto de Ballintoy & Segunda \\
\hline Jas Tierras de la tormenta & Cuevas de Cushendun & \multirow{2}{*}{ Segunda } \\
\hline Las mentas ue ta tominemia & Larrybane & \\
\hline Las Islas del Hierro & Bahía de Murlough & Tres \\
\hline $\begin{array}{l}\text { Casa Austara y el Castillo Negro (donde viven } \\
\text { Jon Snow y Guardia de la Noche) }\end{array}$ & Cantera de Magheramorne & Quinta \\
\hline Aguasdulces & Corbet & Sexta \\
\hline \multicolumn{3}{|l|}{ MALTA } \\
\hline Lugar de Juego de Tronos & Escenario real & Temporada \\
\hline La puerta de Desembarco del Rey & Puerta de Mdina & Primera \\
\hline $\begin{array}{l}\text { La puerta de la Fortaleza Roja en Desembarco } \\
\text { del Rey }\end{array}$ & Fuerte Ricasoli & Primera \\
\hline La boda de Daenerys y Khal Drogo & Azure Window (Gozo) & Quinta \\
\hline La casa de Illyrio Mopatis & Los jardines del Palacio de Verdala & Quinta \\
\hline La Fortaleza Roja & El Palacio de San Anton & Primera \\
\hline La mazmorra de la Fortaleza Roja & Fuerte St Angelo & Quinta \\
\hline Gran Septo de Baelor & Fuerte Manoel & Quinta \\
\hline \multicolumn{3}{|l|}{ Escocia } \\
\hline Lugar de Juego de Tronos & Escenario real & Temporada \\
\hline Invernalia & El Castillo de Doune & $\begin{array}{l}\text { A partir de la primera } \\
\text { temporada }\end{array}$ \\
\hline
\end{tabular}

Fuente: Elaboración propia con base en Skyscanner

Se puede afirmar que el mapa interactivo más amplio, más trabajado y con más información es el de Juego de Tronos, la cual, además, es la serie protagonista de esta investigación. Por tanto, a continuación se muestra con mayor detalle su mapa cinematográfico. En él se pueden distinguir las localizaciones de la serie en Irlanda del Norte (figura 1).
Es posible "jugar" con el zoom para ampliar o reducir el mapa, en función de lo que se quiera ver o leer. Lo interesante de este mapa es que al hacer clic sobre cualquiera de los números muestra información e imágenes sobre las escenas rodadas en dicho lugar. 


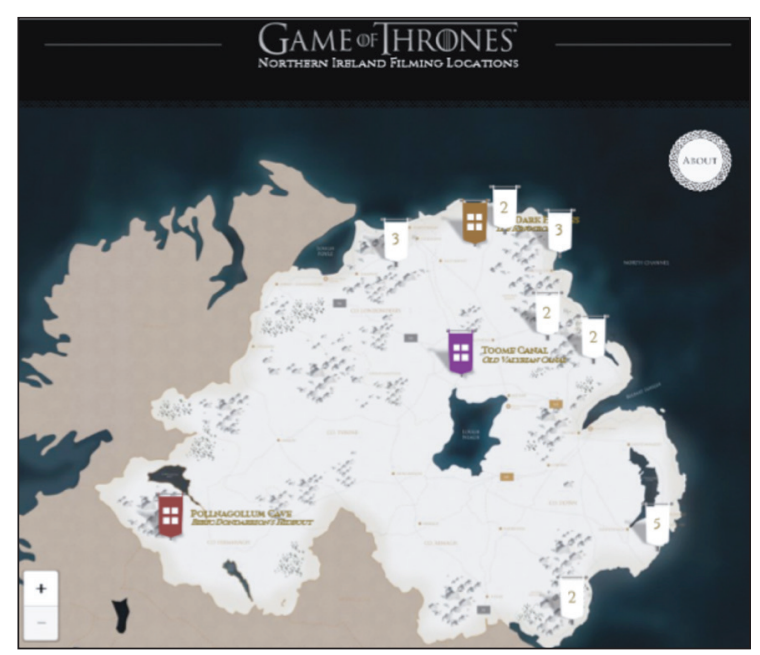

FIGURA 1. Alianzas y localizaciones de Juego de Tronos en Irlanda del Norte. Fuente: Oficina de turismo de Irlanda del Norte.

\section{Metodología}

Hasta ahora se ha visto el éxito del turismo cinematográfico y derivado de las series, y, por otra parte, el éxito de una serie en concreto, Juego de Tronos. A continuación, se plantean los objetivos que se persiguen en la parte empírica del estudio: 1. Verificar que las series con grandes audiencias son atractivas como "emplazamiento de destinos turísticos"; 2. Analizar si se hace un uso activo de la serie cómo herramienta de promoción de los destinos; y 3. Analizar si se crean productos turísticos como consecuencia o en vinculación con la serie Juego de Tronos.

A fin de llevar a cabo esta investigación, se ha optado por la técnica cualitativa de análisis de contenido. Según Berelson (1952, p. 18), es "una técnica de investigación para la descripción objetiva, sistemática y cuantitativa del contenido manifiesto de la comunicación". Para Hostil (1969, p. 5), "el análisis de contenido es una técnica de investigación para formular inferencias identificando de manera sistemática y objetiva ciertas características específicas dentro de un texto". Krippendorff (1990, p. 28), por su parte, plantea que es "una técnica de investigación destinada a formular, a partir de ciertos datos, inferencias reproducibles y válidas que puedan aplicarse a su contexto".

La muestra a analizar serán las páginas web de los diferentes destinos turísticos en que se ha grabado la serie. Para esto, se realiza un primer análisis de las páginas web oficiales de los países y destinos que aparecen en las series, a fin de seleccionar aquellas en la que se hace alguna mención a la serie (véase la tabla 6).

TABLA 6. Muestra de páginas web analizadas

\begin{tabular}{|c|c|c|c|}
\hline DESTINO & DESTINOS & WEB OFICIAL & $\begin{array}{l}\text { ALUSIÓN A LA } \\
\text { SERIE }\end{array}$ \\
\hline \multirow{14}{*}{ España } & & http://www.spain.info/es/ & Sí \\
\hline & Andalucía & http://www.andalucia.org/es/ & Sí \\
\hline & \multirow{3}{*}{ Sevilla } & http://www.visitarsevilla.es/ & Sí \\
\hline & & http://www.visitasevilla.es/ & Sí \\
\hline & & http://www.sevilla.org/areas-tematicas/turismo/ & No \\
\hline & \multirow{2}{*}{ Córdoba } & http://www.turismodecordoba.org/ & No \\
\hline & & http://www.cordobaturismo.es/ & No \\
\hline & \multirow{2}{*}{ Peñíscola } & http://www.peniscola.es/ & Sí \\
\hline & & http://www.peniscola.org/ & No \\
\hline & \multirow{4}{*}{ Comunidad Valenciana } & http://comunitatvalenciana.com/ & No \\
\hline & & http://www.turisme.gva.es/ & No \\
\hline & & http://www.turismocomunidadvalenciana.info & No \\
\hline & & http://www.turisvalencia.es/es/home & No \\
\hline & Navarra & http://www.turismo.navarra.es/esp/home/ & No \\
\hline
\end{tabular}




\begin{tabular}{|c|c|c|c|}
\hline DESTINO & DESTINOS & WEB OFICIAL & $\begin{array}{l}\text { ALUSIÓN A } \\
\text { LA SERIE }\end{array}$ \\
\hline \multirow{7}{*}{ España } & \multirow{2}{*}{ Almería } & http://www.turismoalmeria.com/ & No \\
\hline & & http://www.turismodealmeria.org/ & No \\
\hline & \multirow{2}{*}{ Barcelona } & http://www.barcelonaturisme.com/wv3/es/ & No \\
\hline & & http://www.barcelona.cat/es/ & No \\
\hline & Gerona & http://www.girona.cat/turisme/cat/index.php & No \\
\hline & \multirow{2}{*}{ Guadalajara } & http://www.turismoenguadalajara.es/ & No \\
\hline & & http://www.guadalajara.es/es/Turismo & No \\
\hline \multirow{3}{*}{ Marruecos } & & http://www.visitmorocco.com/index.php/esl/Inicio & No \\
\hline & AïtBen-Haddou & $\begin{array}{l}\text { http://www.turismomarruecos.net/que-ver/ } \\
\text { ait-benhaddou.html }\end{array}$ & No \\
\hline & Essaouira & $\begin{array}{l}\text { http://www.turismomarruecos.net/essaouira/ } \\
\text { destinos/costa-atlantica/essaouira.html }\end{array}$ & No \\
\hline \multirow{3}{*}{ Islandia } & & http://es.visiticeland.com/ & No \\
\hline & & http://www.turismoislandia.es/ & Sí \\
\hline & Grjótagjá & http://beiceland.is/grjotagja & No \\
\hline \multirow{9}{*}{ Croacia } & & $\begin{array}{l}\text { http://croatia.hr/es-ES/Oficinas-representativas/ } \\
\text { Espana }\end{array}$ & Sí \\
\hline & Dubrovnik & http://www.dubrovnik-online.com/ & Sí \\
\hline & (Dalmacia) & https://www.dubrovnikcity.com/guidedtours.htm & No \\
\hline & Torre minceta (Dalmacia) & http://www.dalmatia.hr/en & Sí \\
\hline & Lovrijenac (Dalmacia) & http://www.dalmatia.hr/en & Sí \\
\hline & Lokrum (Dalmacia) & http://www.dalmatia.hr/en & Sí \\
\hline & Trsteno (Dalmacia) & http://www.dalmatia.hr/en & Sí \\
\hline & Sibenik & http://www.sibenik-croatia.info/links.htm & No \\
\hline & Krka (Lozovac) & http://www.np-krka.hr/en/ & No \\
\hline \multirow{3}{*}{$\begin{array}{l}\text { Irlanda del } \\
\text { Norte }\end{array}$} & & http://www.ireland.com/es-es/ & Sí \\
\hline & $\begin{array}{l}\text { The Dark Hedges (condado de } \\
\text { Ballymoney) }\end{array}$ & http://www.visitballymoney.com/ & Sí \\
\hline & $\begin{array}{l}\text { Cuevas Cushendun (condado } \\
\text { Antrim) }\end{array}$ & https://www.visitbritain.com/ & Sí \\
\hline \multirow{5}{*}{ Malta } & & http://www.visitmalta.com/es/ & No \\
\hline & & http://www.viajarmalta.com/ & No \\
\hline & & http://www.voyamalta.com/ & Sí \\
\hline & & http://www.malta.com/ & No \\
\hline & Azure Window (Gozo) & http://www.visitgozo.com/es/ & No \\
\hline Escocia & & https://www.visitscotland.com/es-es/ & No \\
\hline
\end{tabular}

Fuente: elaboración propia.

En todas las páginas web que sí hacen alusión a Juego de Tronos, se analizará una serie de ítems que arrojen información sobre los objetivos planteados, así como otra información adicional que valoren estas páginas. Para esto se han propuesto los siguientes ítems de análisis:

1. Idiomas en qué se oferta la página web.
2. Existencia de un menú de turismo cinematográfico/series (acceso directo).

3. Existencia de un acceso directo a información de la serie.

4. Uso de la serie como promoción turística en la página inicial de la web. 
5. Existencia de productos/paquetes turísticos vinculados a la serie.

6. Disponibilidad de los productos/paquetes vinculados a la serie (estacionalidad).

7. Nivel de detalle/explicación de estos productos.

8. Presencia de mapa cinematográfico de la serie.

9. Contactos para solicitar más información.

10. Estadísticas de visitantes a raíz de la serie.

11. Herramientas comunicativas utilizadas vinculadas a la serie (acceso a redes sociales de la serie o promoción turística de la serie).

12. Comentarios de los clientes.

Con el análisis de dichos ítems se da respuesta a los objetivos planteados en la presente investigación. Los ítems 8 a 11 contribuyen a alcanzar el objetivo 2; los ítems 3, 5, 6 y 7 se asocian con el objetivo 3. Los ítems 2 , 4 y 12 verifican el objetivo 1. El ítem 1 ("Idiomas en qué se oferta la página") ayuda a conocer el alcance o difusión que busca la página, de modo que llegue a un mayor o menor número de usuarios.

\section{Principales resultados}

En la web de turismo de España (www.spain. info), se puede obtener información en una treintena de idiomas. Hay un espacio dedicado a la serie denominado "Propuestas de viajes", en el que se hace una descripción de todas las provincias españolas que fueron escenario de Juego de Tronos, y se detalla en cada una los lugares exactos. Se muestran imágenes de los actores en el rodaje, el enlace de un video en el que se puede ver un resumen de los rodajes en todos los escenarios españoles y opiniones de los propios actores; con esa información, el turista tiene la posibilidad de organizar una ruta por su cuenta. Además, existe un espacio en la página web en el que cabe la posibilidad de reservar la ruta ofertada en Sevilla.

Según un análisis de Tripadvisor, tras el rodaje de la quinta temporada de la serie, Osuna ha recibido un 35\% de búsquedas más que en los dos últimos años, y Sevilla un 21\%. Osuna es el destino más económico, de hecho, pues ha bajado los precios del alojamiento en un 23\% del 2013 al 2015.
La página web de Andalucía dedica un espacio a "Destinos de cine". Al igual que ocurría con la página web de España, se describe el paso por cada uno de los escenarios, pero no hay una oferta directa de un producto. Se promociona básicamente Sevilla. Esta información se encuentra disponible en los principales idiomas: castellano, inglés, francés y alemán. Concretamente, en Sevilla existe la web www.visitarsevilla.es, disponible solo en castellano, en la cual, a través de un menú desplegable, se accede a un espacio dedicado a "Planes con encanto"; uno de los planes ofertados es la "Ruta por los escenarios de Juego de Tronos en Sevilla".

Otra web de Sevilla, www.visitasevilla.es, simplemente nombra la serie como un acontecimiento destacado, y aporta información muy breve, pero en cinco idiomas. Dentro de Andalucía destaca Sevilla como enclave de rodaje, cuya difusión ha contribuido a promocionar el turismo durante todo el año, incluso con la oferta de rutas en temporada baja.

Respecto a Peñíscola, es cierto que existe una pestaña en la página principal sobre "Peñíscola de cine", pero Juego de Tronos tan solo aparece unos segundos en un video promocional, y no hay más información o apuntes sobre la serie en esta web.

En el caso del destino Islandia, http://www. turismoislandia.es/, la web está disponible en castellano. Nada más abrir la página se puede ver la oferta de la ruta de Juego de Tronos por Islandia. Aporta mucha información sobre cada escenario y el contacto para realizar reservas. Se muestra un acceso directo tanto a la web de la ruta oferta como a la red social de Facebook.

Además, a través de la página web www.guiadeislandia.es, se puede leer una descripción detallada del rodaje de la serie en este lugar. Desde la página se facilita un enlace para aquellos turistas que quieran realizar la excursión guiados por guías expertos en la serie y de la zona. La ruta tiene una duración de entre seis y siete horas; la salida es a las 9: 00 a. m. de la oficina de turismo de Reykjahlia. En la página web aconsejan llevar ropa de abrigo e impermeable, buen calzado de trekking y gafas de sol. La ruta se realiza con un mínimo de dos personas, es de fácil acceso y se puede realizar durante todo el año. La reserva se hace a través de la página web.

Esta misma ruta se oferta a través de un acceso directo en la página web www.visitaskja.com, la cual solo está disponible en inglés y la reserva se puede realizar en línea. 
TABLA 7. Resultados obtenidos, análisis de contenido de Juego de Tronos ( $1^{\text {a }}$ parte)

\begin{tabular}{|c|c|c|c|c|c|c|}
\hline DESTINO & IDIOMAS (N.ํㅜ) & MENÚ & $\begin{array}{l}\text { ACCESO } \\
\text { DIRECTO }\end{array}$ & $\begin{array}{l}\text { PROMOCIÓN } \\
\text { EN PORTADA }\end{array}$ & $\begin{array}{l}\text { PRODUCTOS, } \\
\text { PAQUETES }\end{array}$ & DISPONIBILIDAD \\
\hline España (país) & 30 & Sí & Sí & No & Sí & $\begin{array}{c}\text { 31/05-30/12 } \\
\text { excepto sábados, } \\
\text { domingos y lunes }\end{array}$ \\
\hline Andalucía (comunidad) & 4 & Sí & Sí & No & No & \\
\hline Sevilla (provincia) & $\begin{array}{c}6 \\
\text { (castellano, inglés, } \\
\text { italiano, francés, } \\
\text { alemán y chino) }\end{array}$ & Sí & Sí & Sí & $\begin{array}{l}\text { Rutas } \\
\text { guiadas }\end{array}$ & $\begin{array}{c}\text { 31/05-30/12 } \\
\text { Excepto sábados, } \\
\text { domingos y lunes }\end{array}$ \\
\hline Peñíscola (municipio) & $\begin{array}{c}3 \\
\text { (castellano, francés } \\
\text { e inglés) }\end{array}$ & Sí & No & No & No & - \\
\hline Islandia (país) & $\begin{array}{c}1 \\
\text { (castellano) }\end{array}$ & Sí & Sí & Sí & Sí & Todo el año \\
\hline Croacia (país) & 16 & No & No & No & No & \\
\hline $\begin{array}{l}\text { Dubrovnik } \\
\text { (Dalmacia) (ciudad) }\end{array}$ & $\begin{array}{c}1 \\
\text { (inglés) }\end{array}$ & No & Sí & Sí & Sí & $\begin{array}{c}\text { Lunes, miércoles y } \\
\text { viernes }\end{array}$ \\
\hline Dalmacia (región) & $\begin{array}{c}7 \\
\text { (croata, inglés, } \\
\text { alemán, polaco, } \\
\text { checo, francés e } \\
\text { italiano) }\end{array}$ & No & Sí & No & Sí & Verano \\
\hline Irlanda del Norte (nación) & $\begin{array}{c}1 \\
\text { (castellano) }\end{array}$ & No & Sí & Sí & Sí & Todo el año \\
\hline $\begin{array}{l}\text { Dark Hedges (Ballymoney) } \\
\text { (zona de la ciudad) }\end{array}$ & 1 & No & No & Sí & Sí & Todo el año \\
\hline \multicolumn{7}{|l|}{ Cuevas Cushendun } \\
\hline $\begin{array}{l}\text { (Antrim) (recurso de la } \\
\text { ciudad) }\end{array}$ & 23 & No & No & No & No & \\
\hline Malta (país) & $\begin{array}{c}1 \\
\text { (castellano) }\end{array}$ & No & Sí & No & Sí & Sábados \\
\hline
\end{tabular}

Fuente: elaboración propia.

En relación con los escenarios de Croacia, se puede encontrar información en 16 idiomas. No se promociona a través de Juego de Tronos ni tiene un menú que haga referencia al turismo cinematográfico, pero sí existe un desplegable de "Ideas de viaje" y, luego, "Detrás de bastidores", en el cual se puede consultar información sobre la serie, imágenes, así como observar un vídeo sobre el rodaje en el destino.

En el portal o página web www.visitacroacia. es se realiza promoción del destino a través de la serie. Esa promoción se basa en un concurso a través de la red social de Facebook, y consiste en una visita guiada para dos personas por los escenarios de Juego de Tronos en Dubrovnik (Desembarco del Rey en la serie), con estancia y vuelos incluidos. Además de la explicación del concurso, existe un espacio dedicado a la explicación detallada de la relación entre los espacios reales y los espacios ficticios de la serie. Además, en esta página web se proporciona el mapa con esas localizaciones para facilitar el recorrido a los turistas. Esta página se presenta en 16 idiomas.

En Croacia, concretamente en Dubrovnik, y en Irlanda del Norte, se ofertan rutas de tres horas de duración a través de una agencia de viajes denominada Viator, la cual tiene su sede en San Francisco. Es tan grande el éxito de la serie (y sigue en aumento), que existen guías especializados en ella (Navarro, 2015).

La página web de Dubrovnik presenta en su página principal un acceso directo para los fanáticos de Juego de Tronos. Es un apartado bastante escueto, en el cual simplemente puede verse un video y la opción de reservar la ruta tanto para grupos como de forma privada. 
TABLA 8. Resultados obtenidos, análisis de contenido Juego de Tronos ( $2^{-a}$ parte). Presencia de mapa cinematográfico, información de contacto, herramientas comunicativas, comentarios de clientes y datos estadísticos derivados de la serie

\begin{tabular}{|c|c|c|c|c|c|}
\hline DESTINO & $\begin{array}{l}\text { NIVEL DE EXPLICACIÓN } \\
\text { DE LA SERIE EN EL } \\
\text { DESTINO ALTO/BAJO }\end{array}$ & $\begin{array}{l}\text { TIENE MAPA } \\
\text { CINEMAT. }\end{array}$ & $\begin{array}{l}\text { POSEE } \\
\text { CONTACTO } \\
0+\text { INFO }\end{array}$ & $\begin{array}{l}\text { PRESENTA } \\
\text { ESTADÍSTICAS }\end{array}$ & $\begin{array}{l}\text { APARECEN } \\
\text { COMENTARIOS } \\
\text { DE CLIENTES }\end{array}$ \\
\hline España & Alto & No & No & No & No \\
\hline Andalucía & Alto & No & No & No & No \\
\hline Sevilla & Alto & No & Sí & No & Solo tres \\
\hline Peñíscola & Bajo & No & Sí & No & No \\
\hline Islandia & Alto & No & Sí & No & No \\
\hline Croacia & Bajo & No & Sí & No & No \\
\hline Dubrovnik (Dalmacia) & Bajo & No & Sí & No & No \\
\hline Dalmacia & Alto & No & Sí & No & No \\
\hline Irlanda del Norte & Alto & No & Sí & No & No \\
\hline Dark Hedges (Ballymoney) & Bajo & No & Sí & No & No \\
\hline Cuevas Cushendun (Antrim) & Bajo & No & Sí & No & No \\
\hline Malta & Alto & No & Sí & No & Sí \\
\hline
\end{tabular}

Fuente: elaboración propia.

La página web del condado de Dalmacia (http://www.dalmatia.hr/) tiene un acceso directo denominado Juego de Tronos dentro del desplegable "Destacado". Ofrece una descripción muy detallada del rodaje de la serie en el lugar, con imágenes y videos. Además, en verano es posible realizar cualquiera de las excursiones que ofertan, y recomiendan siempre reservar con dos semanas de antelación debido a su éxito. En esta página web existen dos enlaces directos relacionados con la serie: el propio tour de Juego de Tronos y la web de Juego de Tronos, de la cual se presenta su mapa cinematográfico (véase la figura 2).

En Irlanda del Norte, la web www.ireland.com ofrece mucha información sobre Juego de Tronos. Han creado un itinerario de tres días de duración, y una de las experiencias que se puede vivir en este recorrido es el tiro con arco en el Castillo de Ward.

La página web www.sobreirlanda.com justifica a Irlanda del Norte como destino privilegiado sobre los otros debido a que la productora de la serie tiene su base allí. La Oficina de Turismo de Irlanda ha creado una ruta de $390 \mathrm{~km}$ por toda la costa de Irlanda para visionar a la perfección todas las localizaciones de la serie.

Belfast está cargada de oferta sobre Juego de Tronos, pues la página web www.gameofthronestours.com ofrece la posibilidad de realizar tres rutas: una por el Norte de Belfast y dos por el sur de esta ciudad. En todas ellas se muestra un mapa interactivo sobre la ruta, información completa del itinerario y recomendaciones de vestuario. La página solo se muestra en inglés, sin posibilidad de cambiar a otro idioma. Se muestra un enlace directo para la realización de la reserva (el coste de las rutas 1 y 2 está entre las 36 y las 40 libras esterlinas, dependiendo del mes en el que se realice, y el de la ruta 3 son 55 libras). Se trata de rutas para mayores de 18 años, no se permiten niños de menos de 12 , y aquellos entre 12 y 18 años necesitan una autorización de sus tutores. Las tres rutas se realizan en autobús, pero se realizan dos rutas a pie, una por la mañana y otra por la tarde. Las dos primeras rutas parten de Belfast, y la tercera de Dublín.

La primera ruta, Isla de Hierro, que es la que se muestra en la figura 3, tiene una duración de 10 horas y se puede realizar entre miércoles y domingo en los meses de verano, y los fines de semana en los meses de invierno.

La segunda ruta, "Invernalia", tiene lugar en el sur de Belfast y una duración de ocho horas. En el mes de agosto está disponible todos los días, y en el resto de los meses es necesario consultar la disponibilidad porque no siempre se realiza los mismos días.

La ruta 3, "Invernalia", también se desarrolla en el sur de Belfast y tiene una duración de once horas. En el mes de agosto está disponible todos 


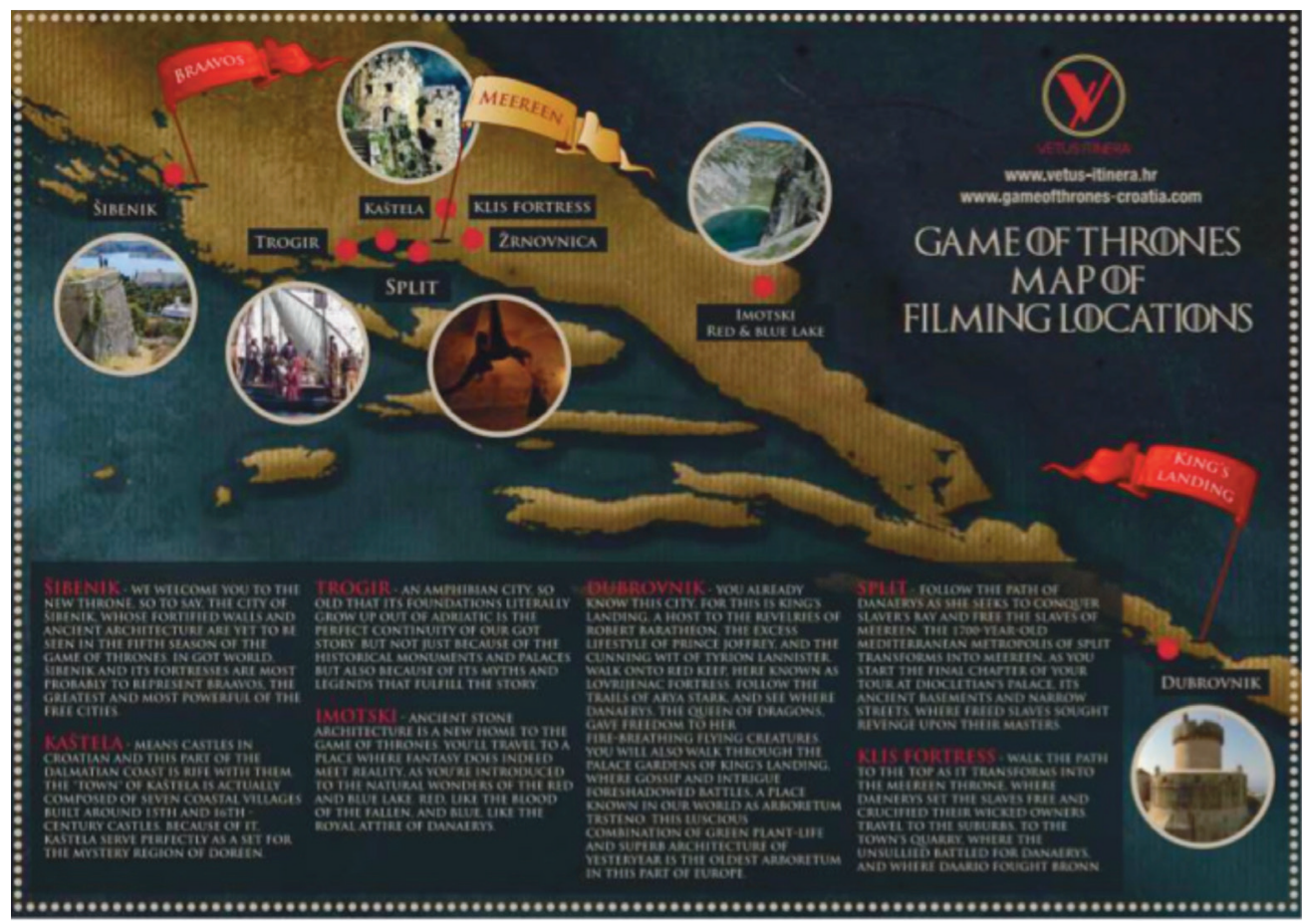

0
$\frac{1}{O}$
$\frac{77}{10}$
$\mathrm{RPE}$

FIGURA 2. Movie map en Croacia. Fuente: http://gameofthrones-croatia.com/

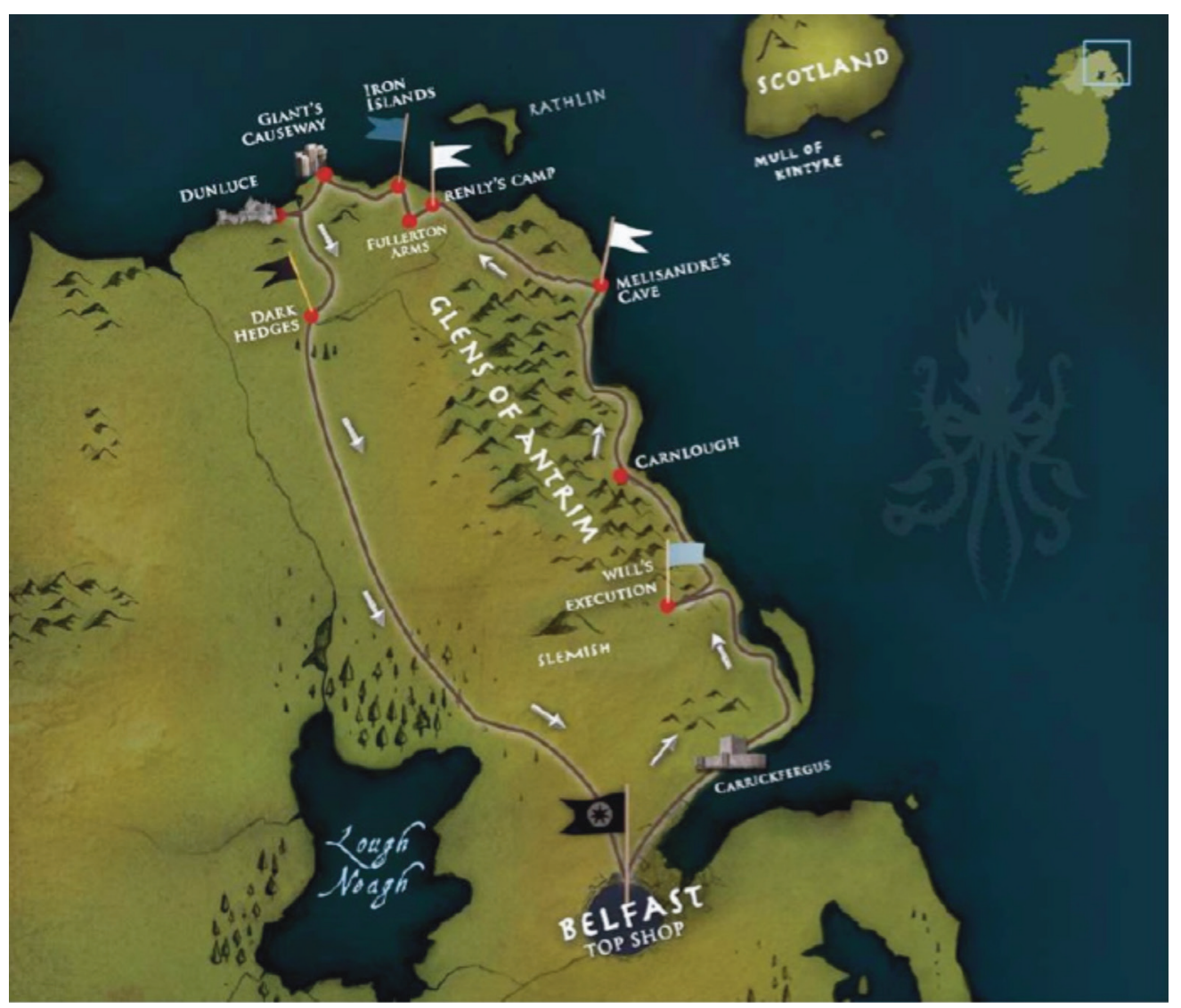

FIGURA 3. Ruta por el norte de Belfast. Fuente: www.gameofthronestours.com 
los días, y en el resto de los meses es necesario consultar la disponibilidad porque no siempre se realiza los mismos días.

La web www.gameofthronesireland.com indica que desde la oficina de turismo de Donegall, Belfast, se oferta una ruta guiada. En esta página web, disponible solo en inglés, se pueden ver fotos, videos y un mapa de la ruta, así como información detallada de esta. Tiene un enlace directo para realizar la reserva. Los escenarios a visitar son Carncastle, donde Ned Stark decapita al desertor de la Guardia de la Noche, Cuchendum, donde Stannis Baratheon lleva a Melisandra a dar a luz, Isla del Hierro o The Dark Hedges, donde Arya Stark escapa de Desembarco del Rey.

Desde la web www.gameofthrones-winterfelltours.com (disponible solo en inglés) se ofertan distintas actividades y paquetes basados en Juego de Tronos: vivir la experiencia de meterse en el papel de algunos actores y realizar tiros con arco en el Castillo de Invernalia, vestirse con trajes como los de los actores, realizar juegos en bicicleta por los escenarios más destacados de la serie con ayuda de un mapa, capas y espadas, o un crucero en barco por Poniente con vistas a los escenarios. Además, cabe la posibilidad de conocer a los perros que salen en la primera temporada de la serie, así como realizar un banquete medieval tematizado (para grupos). Esta misma página oferta la posibilidad de comprar souvenirs o bonos para alguna ruta o actividad.

Para terminar con Irlanda del Norte, cabe indicar que existe un hotel tematizado sobre la serie: The Cuan, su página web es www.thecuan. com/game-of-thrones/. Este hotel se eligió para situar la puerta de Juego de Tronos, dada su cercanía a los escenarios de rodaje y por haber alojado a los actores durante este.

Respecto a la web www.visitballymoney.com, solo disponible en inglés, muestra como portada una imagen de Juego de Tronos, pero no ofrece mucha información sobre la serie.

La web www.visitbritain.com está disponible en la mayoría de los idiomas, pero no se encuentra mucha información sobre la serie. Simplemente se nombran algunos lugares por los que pasó la serie.

Por otra parte, www.voyamalta.com, aunque no hace promoción de la serie en la página principal, ni tiene un desplegable de turismo cinematográfico, sí tiene uno de "excursiones en Malta" donde poder seleccionar la de Juego de Tronos. Otra web de Malta, www.descubremalta.com, propone un recorrido para aquellos turistas que lo quieran hacer por su cuenta. Podría comenzar en el Verdala Palace y terminar el recorrido en el Fuerte Manoel (allí Ned Stark admite ser un traidor).

Tras realizar el análisis de cada una de las páginas web, resulta curioso que no se ha encontrado ningún mapa cinematográfico en ninguna página web, pero sí existen muchos mapas cinematográficos en páginas secundarias o no oficiales (véase la figura 4).

\section{Conclusiones}

El objetivo de la presente investigación es verificar si Juego de Tronos se usa como herramienta promocional de los destinos en que se ha grabado, y si se crean productos turísticos derivados de ella, de manera que contribuyan así de modo positivo al desarrollo del sector turístico. Tras el análisis realizado, se intuye que esto se cumple. Se está ante una serie atractiva como emplazamiento de destinos turísticos, ya que en la mayor parte de los destinos de rodaje se ha conseguido incrementar el interés y el número de búsquedas en línea (por ejemplo, el caso de Osuna, en España). En mayor o menor medida, los destinos la utilizan para realizar la promoción turística y, en algunos casos, se crean productos relacionados con la serie. Gracias a este fenómeno existen guías turísticos especializados en la serie, agencias que crean rutas tematizadas, así como algún hotel tematizado con actividades (tiro de arco o salidas en bicicleta por ubicaciones de la serie, entre otras). Ejemplo de lo anterior es Sevilla, donde se ha contribuido de forma positiva a la desestacionalización turística, ya que se ofertan rutas en temporada baja hasta el 30 de diciembre, así como Islandia e Irlanda del Norte, en donde se ofertan durante todo el año.

En este trabajo se tuvieron cuenta 45 páginas web oficiales, de las cuales solo en 16 se promociona el destino a través de Juego de Tronos. Aunque muchas páginas realizan una promoción basada en la serie, falta todavía crear más oferta relacionada con ella. Se considera necesario incluir en las páginas webs oficiales mapas cinematográficos que hagan referencia a la serie.

Tras comparar los países analizados, es Irlanda del Norte donde se percibe un trabajo más amplio sobre la información y posibles rutas de Juego de Tronos, aunque cierto es que eso tiene una clara explicación, y es que en Irlanda del 


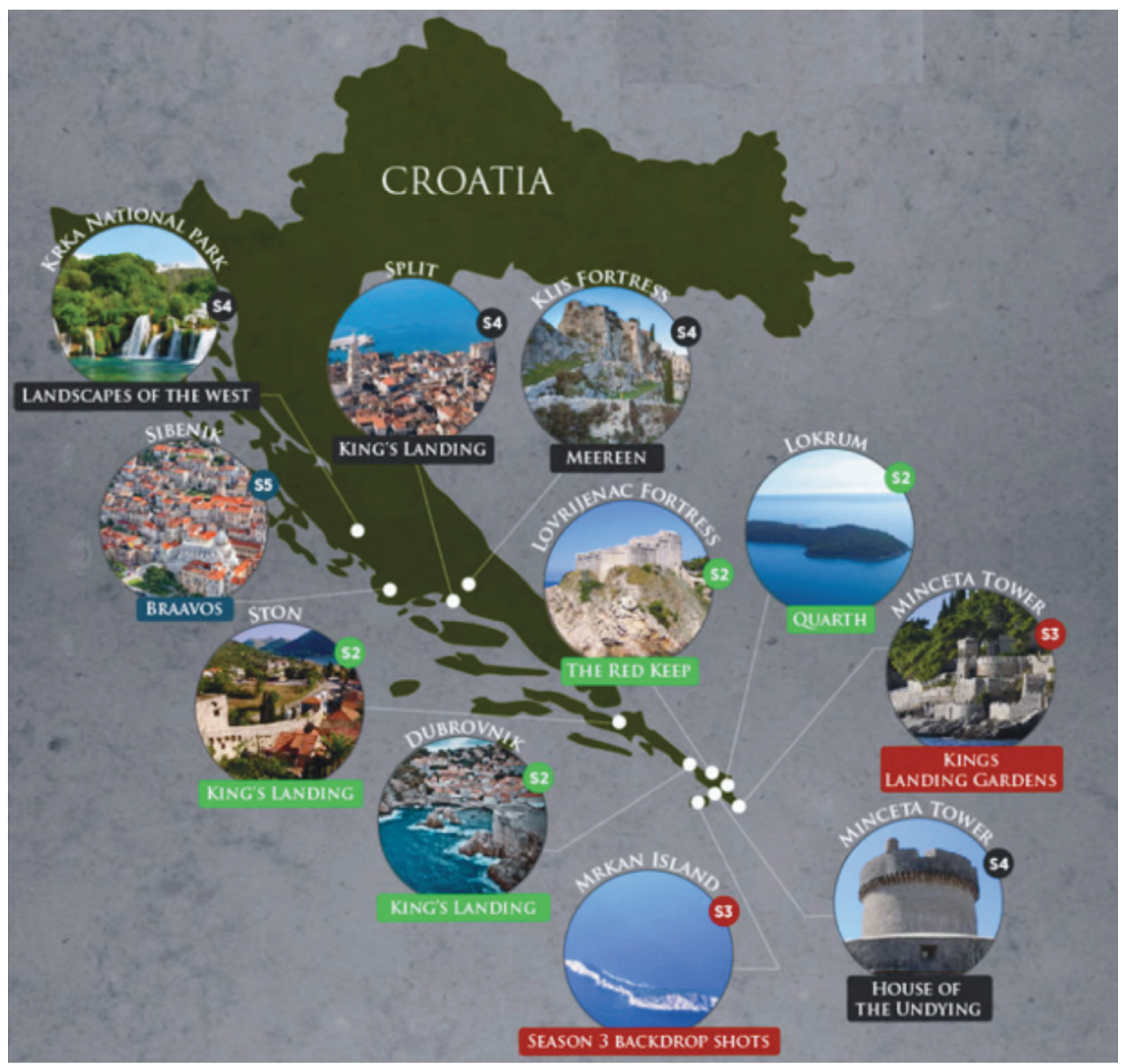

FIGURA 4. Mapa cinematográfico en Croacia. Fuente: http://geektyrant.com/news/game-of-thrones-map-ofevery-filming-location

Norte se encuentra la sede de нво, la productora de la serie.

Se puede afirmar que todas las localizaciones que sirvieron de rodaje para la serie Juego de Tronos se han visto afectadas de forma positiva de algún modo, bien sea por incremento de turistas, mayor número de búsquedas en línea o creación de productos y rutas vinculadas a la serie, de modo que aumenta así la oferta turística del destino y ofrecen más alternativas a los turistas.

Esta investigación confirma, a priori, la teoría de Urry (1990), según la cual "el turista desea reconocer, revivir con la mirada, las imágenes que han sido anticipadas por la promoción turística, por encarnar en éstas su anhelo de autenticidad". Esto en razón a que se han obtenido datos del importante incremento de las visitas turísticas en los destinos que sirvieron de escenario en el rodaje de series, lo cual se traduce en un indicio de que las imágenes evocadas en las series han servido como herramienta promocional del destino. Serían necesarios estudios detallados sobre la motivación de visita del turista para confirmar que la serie es el motivo principal o secundario de visita, pero el incremento de turistas en todas las zonas de grabación de series relevantes, entre ellas Juego de Tronos, hace pensar que la grabación de la serie está en gran medida vinculada con ello.

La repercusión de las series en el turismo dependerá del éxito de la serie, del número de seguidores o seguidores que esta tenga. No es posible saber durante cuánto tiempo durará su éxito turístico, pero uno se podría aventurar a estimar un periodo largo gracias a su elevado número de fanáticos.

Los resultados obtenidos en la investigación concluyen que, a pesar de que la serie ha conseguido captar a muchos espectadores que están 
dispuestos a viajar a los destinos vistos en la pantalla, todavía no es común encontrar un apartado referente o dedicado al turismo cinematográfico en las páginas web de los destinos turísticos, por lo que se debe seguir trabajando en esta tipología turística que día a día cobra más importancia en el sector turístico. El turismo inducido a través de las series audiovisuales empieza a utilizarse como herramienta promocional turística, aunque se encuentra aún en una etapa de introducción en el ciclo de vida de este producto. Al igual que ya está demostrada la efectividad del turismo cinematográfico, el turismo inducido a través de series podría seguir la misma mecánica y atraer también a un gran número de turistas o visitantes. Incluso, es factible llegar a acuerdos de cooperación entre productoras de series audiovisuales y algún ente gestor turístico, en busca de sinergias que favorezcan a ambos sectores. Incluir un destino turístico en una serie audiovisual es una eficaz herramienta promocional, ya que proporciona visibilidad a largo plazo, se crea empatía con el espectador, se puede llegar a tener grandes audiencias e, incluso, si el destino tiene un importante peso en la trama, puede llegar a equipararse a un personaje más y el impacto puede llegar a ser mayor. Los expertos apuestan por una mayor efectividad promocional de un destino turístico en una serie que en un spot publicitario.

Por último, como futuras líneas de investigación se pretende realizar una continuidad de la investigación sobre las próximas temporadas de Juego de tronos y analizar su evolución turística, así como contrastar las zonas de grabación con datos turísticos, y verificar así si en la misma línea siguen incrementándose las visitas.

\section{Referencias}

Araújo, N. y Fraiz, J. A. (2011). El turismo inducido a través de las series de ficción y su papel dentro del turismo experiencial. El caso de la serie de ficción Doctor Mateo. XVI Congreso AECIT, Mijas, Málaga.

Araújo, N. y Fraiz, J. A. (2013). Las series audiovisuales como herramienta promocional de un destino turístico: el caso de España. Investigaciones Europeas de Dirección y Economía de la Empresa, 19(1), 8-15.

Berelson, B. (1952). Content analysis in communication research. Glencoe: Free Press.

Bernad, E. y Fernández, C. (2014). Prácticas de city-marketing: rentabilizando la imagen oriental de Granada mediante la comunicación expandida del territorio. Análisis audiovisual y publicitario actuales, 47.

BitTorrent. (2016, junio 15). BitTorrent [software]. Recuperado de http://www.bittorrent.com/lang/es

Buchmann, A., Moore, K. y Fisher, D. (2010). Experiencing film tourism: authenticity and fellowship. Annals of Tourism Research, 37(1), 229-248.

Busby, G. y Klug, J. (2001). Movie-induced tourism: The challenge of measurement and other issues. Journal of Vacation Marketing, 7(4), 316-332.

Domínguez Azcue, J. (2014). Análisis de la imagen de destino a través de la cinematografía: Málaga. Universidad de Málaga.

Hellín, J. A. y Martínez, S. (2009). Marca turística y movie maps. Identidad, cine y publicidad como producto de consumo. Signos do consumo, 1(2), 142-158.

Hernández, J. (2004). Turismo inducido. La configuración de la imagen turística de Sevilla a través del cine comercial. I Congreso Internacional Patrimonio, Desarrollo Rural y Turismo en el Siglo XXI, Universidad de Sevilla.

Hosteltur (noviembre, 2011). Promoción turística y series de televisión, estrategia de éxito. Recuperado de: https://www.hosteltur.com/147810_promocion-turistica-series-television-estrategia-exito. html

Holsti, O. R. (1969). Content analysis for the social sciences and humanities. Reading. MA: Addison-Wesley (content analysis).

Hudson, S. y Ritchie, J. B. (2006). Promoting destinations via film tourism: an empirical identification of supporting marketing initiatives. Journal of Travel Research, 44(4), 387-396.

Kim, H. y Richardson, S. (2003). Motion picture impacts on destination images. Annals of Tourism Research, 30(1), 216-237.

Krippendorff, K. (1990). Metodología de análisis de contenido: teoría y práctica. Piados Comunicación, 1(42), 269-279.

Marcos, Natalia. (2014, agosto 16). De turismo por las series. Elpaís.com. Recuperado de http:// cultura.elpais.com/cultura/2014/08/15/television/1408121395_458848.html

Martínez, A. (2008). El cine como soporte didáctico para explicar la evolución del viaje y para la actividad turística. Cuadernos de Turismo, 22, 145-163.

Martínez, S. y Hellín, P. A. (2014). La ficción audiovisual como instrumento para la creación de marca territorial: de brand placement al place branding. El nuevo diálogo social, 40(3), 613-626.

Mathieson, A. y Wall, G. (1982). Tourism: economic, physical and social impacts. Londres: Longman.

Méndiz, A. (2011, December). Emplazamiento de ciudades en el cine ("City placement"): Una estrategia 
de doble sentido entre la producción cinematográfica y la industria del turismo. La comunicación pública, secuestrada por el mercado. En Actas-III Congreso Internacional Latina de Comunicación Social-IIICILCS-Universidad de La Laguna, dic. 2011

Movilla Mengual, L. A. (2009). La función de comunicación comercial del product placement y su influencia en los sistemas de producción audiovisual (tesis doctoral). Universidad Complutense de Madrid, Madrid, España.

Muñoz, A. (2002). La imagen de un destino turístico: concepto e instrumentalización. Una aproximación a la comunicación como instrumento de política. Madrid: Papeles OMT, DRH, Organización Mundial del Turismo.

Navarro, I. (2015). Influencia de las series de televisión en el turismo: el caso de Isabel. (trabajo de grado), Universidad de Valladolid.

Redondo, I. y Bernal, J. (2015). Product placement: una revisión teórico-práctica de sus capacidades y limitaciones. Interciencia, 40(12), 827-833.

Rodríguez, M. L. y Fraiz, J. A. (2010). Consideraciones estratégicas para la promoción del turismo en Galicia a través del cine. Revista Galega de Economía, 19(2), 155-164.

Rodríguez, M. L., Fraiz, J. A. y Alén, M. E. (2013). Nuevos segmentos turísticos culturales. Una aproximación al comportamiento del consumidor turístico cinematográfico. Cuadernos de Turismo, 32, 259-279.

Roesch, S. (2009). The experiences of film location tourists. Clevedon: Channel View Publications.

Urry, J. (1990): The tourist gaze. London: Sage.

Vives García, M. (2013). Turismo inducido por el cine: aplicación del caso a la ciudad de Barcelona. Girona: Universitat de Girona.

\section{Referencias online}

BitTorrent http://www.bittorrent.com/lang/es [15/06/2016]

Blog GoEuro: http://blog.goeuro.es/localizaciones-de-juego-de-tronos-que-todo-fan-deberia-visitar/[18/03/2016].

Diario información: http://www.diarioinformacion. com/blogs/juego-de-series/las-series-mas-esperadas-de-2016.html [18/03/2016].

El mundo: http://www.elmundo.es/television/2015/07/30/55b8fab522601db80c8b4595. html [25/05/2016]

Fórmula TV: http://www.formulatv.com/series/ [21/03/2016].

Game of Thrones: http://gameofthrones-croatia.com/ [10/06/2016].

Hoja de rutas: http://www.hojaderutas. com/2014/04/juego-de-tronos-escenarios-reales. html [20/05/2016].

Movie maps: https://moviemaps.org/movies/n7 [02/04/2016].

Oficina de turismo de Irlanda del Norte: http://www. discovernorthernireland.com/gameofthrones/ [28/05/2016].

Público: http://www.publico.es/culturas/10-series-mas-descargadas-2015.html [20/03/2016].

Sensacine: http://www.sensacine.com/series-tv/mejores/ [18/03/2016].

Skyscanner: http://www.skyscanner.es/noticias/descubre-los-lugares-donde-se-rodo-juego-de-tronos [20/05/2016]

Tripadvisor: http://blog.tripadvisor.es/2015/07/02/ aumenta-el-interes-turistico-por-osuna-y-sevilla-lugares-derodaje-de-juego-de-tronos/ [06/06/2016].

Turespaña: http://www.tourspain.es/es-es/Paginas/ index.aspx [15/04/2016]. 
